\title{
A BROTHERHOOD AT QUMRAN? METAPHORICAL FAMILIAL LANGUAGE IN THE DEAD SEA SCROLLS
}

\author{
Jutta Fokiranta and Cecilia Wassen
}

The Essene communities were characterized by a strong bond of unity among their members, according to Philo and Josephus. Philo explains

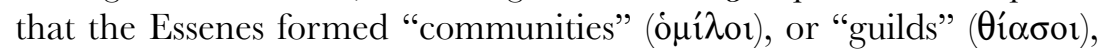
in which they shared resources and had common meals (Hypothetica 11.1-5; Prob. 85-6). Josephus similarly highlights the practice of sharing property amongst the members (B.J. 2 122) and claims that the members showed greater attachment to one another than did members of other sects (B.J. 2 119). Given the strong bonds among the Essenes, it comes natural for both Josephus and Philo to describe the relationship between members in family terms. Hence, Josephus compares the shared property of members to that of brothers (B.J. 2 122). Philo likens the relationship between older and younger members with that of fathers and sons (Hypothetica 11.13) as well as parents and children (Prob. 87). In addition, Philo argues that the Essenes rejected slavery since they considered all humans equal and essentially viewed them as brothers (Prob. 79). ${ }^{1}$

Turning to the Dead Sea Scrolls (DSS) which we associate with the Essenes, one of the key terms for self-identification in some of the sectarian documents is yahad, suggesting again a strong unity among the members. ${ }^{2}$ Consequently, modern commentators have not hesitated

\footnotetext{
1 The traditional view of the Essenes as brotherhood has influenced earlier translations of the Greek authors: Thackeray translates "brothers" when the Greek reads "one of their own" (B.J. 2 127) and adds a clarifying "fraternity," which does not appear in the Greek (B.J. 2 137; Iosephus Flavius 1956). Dupont-Summer (1973, Eng. trans.

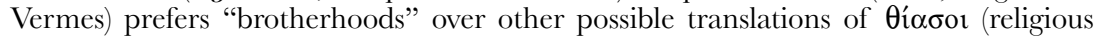
guilds, companies, clubs, or fraternities).

${ }^{2}$ Weinfeld $(1986,13-15)$ suggests that the use of the term יחד was influenced by

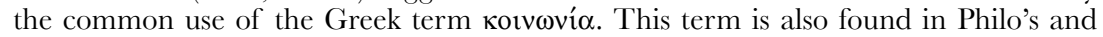
Josephus's descriptions of the Essenes. For other organizational terms, e.g., רבים and םרך, and their Hellenistic equivalents, see Weinfeld 1986, 10-16.
} 
to describe the sectarian community as a brotherhood. "Brother(s)" is, however, rarely the term of choice to describe fellow members in the sectarian writings of the DSS. The question thus arises, why not? And what are other, if any, preferable familial metaphors used to express the self-identity and the relationships in the Qumran sect, ${ }^{4}$ and why are these chosen?

This study locates familial terminology in the Scrolls, explores where it is used metaphorically and how it then expresses various relationships, particularly between members, but also between members and outsiders and between humans and God. ${ }^{5}$ We will analyze the use of household and parent-child metaphors as well as brother metaphors. Household terminology often says something about hierarchy. A key question we will address is whether different family metaphors express egalitarian or hierarchical social structures. For example, although the same sense of unity and affection may be evoked by father-and-sonmetaphors as that of brothers, the implied hierarchical relationships are different. We will also inquire as to whether there is evidence of a negative stance toward the biological family. The focus of this study is on the sectarian literature, particularly the Community Rule (S), the Damascus Document (D), the Rule of the Congregation (1QSa), and the Hodayot $\left(1 \mathrm{QH}^{\mathrm{a}}\right)$.

Before we begin our investigation into specific familial terms in the Scrolls, we need to consider the way in which metaphors function within language. ${ }^{6}$ We will highlight aspects from metaphor theory, which illuminate the built-in character of metaphors in language and

\footnotetext{
${ }^{3}$ For example, Frank Moore Cross $(1995,74)$ identifies "brotherhood" as one of several characteristics that the sectarians and the early Christians share: "[a] unity (through the Spirit), brotherhood, love of one's fellow, the breakdown of the disparity between the (wicked) rich and the (oppressed) poor." Whereas the Danish translation of the Scrolls (Ejrnæs 2003) translates yahad as "broderskab" ("brotherhood") in the Community Rule, the Norwegian one (Elgvin 2004) prefers "Samfunnet" ("the Fellowship").

${ }^{4}$ By "Qumran sect" we refer to the sect that produced or preserved the Dead Sea Scrolls. We presume that this sect was divided into different branches, as evidenced by the Damascus Document $(\mathrm{D})$, and included settlements at different locations, with Qumran possibly being the headquarters. We acknowledge that the term yahad refers to a broad part of the sect and should not be identified exclusively with the particular settlement at Qumran (Elgvin 2005, 273-79).

${ }^{5}$ For a study on divine sonship (with reference to angels, Israel, the king, and the Messiah), see García Martínez 2006. Our study complements his in that we concentrate on familial metaphors concerning members.

${ }^{6}$ Aasgaard $(1998,119$, n. 1) points out that cultural anthropology uses the concept "fictive kinship" for metaphorical, non-literal use of family terms. This terminology is
} 
in human thinking. In addition, insights from social identity theory will shed light upon the meanings of these metaphors within the Qumran sect, particularly within the context of how people perceive themselves and others as group members.

\section{Metaphor Theory and Social Identity Approach}

Metaphors can be defined as structures that provide an understanding of one thing in terms of another thing. In their classic study on metaphors, George Lakoff and Mark Johnson (1980) view most of our conceptual system as metaphorically structured. ${ }^{7}$ One example is the concept "love." This concept can be structured, for example, according to the metaphor "love is a journey." The metaphor is then reflected in expressions such as "Look how far we've come"; "We're at a crossroads"; "We've gotten off the track" (Lakoff and Johnson 1980, 44-45). The source domain (e.g., journey) serves as the area which is used to understand the target domain (e.g., love). Often concepts are not noticed as being metaphorical; only a closer look at our everyday experiences may reveal their metaphorical structuring. ${ }^{8}$ If Lakoff and Johnson are correct, metaphors are not about language only, but about structuring our conceptual system and everyday activities; metaphors make sense of our perceptions and experiences, guide our categorization, and direct our actions. They are "principle vehicles for understanding" (1980, 159).

One essential function of metaphors, as Lakoff and Johnson observe, is to highlight some aspects of the target domain and to hide or downplay others. For example, the expression "She's driving me wild" highlights the lack of control associated with love, while hiding other dimensions, such as "love is cooperation" and "love is war." Moreover, the source domain is used selectively in metaphors: the metaphor "love

\footnotetext{
also common in NT studies. In this paper, we prefer "metaphors" and "metaphorical familial terminology/language," following the terminology of metaphor theory.

7 We will primarily draw on Lakoff and Johnson's study, which provides the tools necessary for our limited inquiry. In recent years, biblical scholars studying ancient metaphors have successfully utilized the work by Lakoff and Johnson (e.g., Dille 2004; Aasgaard 2004). Its validity and further developments are shown, e.g., by Kövecses 2002. See also their later work, Lakoff and Johnson 1999.

8 The expression "you are wasting my time" reflects the metaphor "time is money." The perception of someone "breaking down" or feeling "rusty" is based on the metaphor "mind is a machine" (mind operates). Humans tend to conceptualize the non-physical in terms of physical (Lakoff and Johnson 1980, 118).
} 
is a journey" utilizes some aspects of journeys (e.g., progressing on the way from one place to another) but ignores others (e.g., vehicles used in journeys). Therefore the meaning and function of metaphors have to be studied case by case. Familial metaphors are no exception: for example, the use of "father" in addressing a Roman Catholic priest highlights certain aspects of the relationship between the priest and the parishioners and gives us a clue of the conceptual structure behind it. Paternity, in this case, represents honor, position, responsibilities, and care; it does not include ideas of being similar in appearance or other aspects of biological paternity. Hence it is important to investigate which parts of the source domain are used in familial metaphors (which family relations and which aspects of them), and what is highlighted and what is hidden by using these metaphors.

If metaphors structured thinking and perception in the Qumran sect, can we capture the conceptual world of the sect by studying (random) linguistic expressions in (randomly) survived texts? The study of familial terminology in the Scrolls is only one - sometimes blurry - window into this world. Nevertheless it is, in our view, a highly informative approach. Yet it is obvious that family is only one among many metaphors by which the Qumran sect structured its conceptual world. For example the metaphor "members are the temple" (e.g., 1QS VIII 5-10) is a different kind of metaphor. In comparison to familial language where both the source and the target domain deal with human relations, the temple imagery instead understands human relations in terms of buildings, rituals, and holy things.

Central to Lakoff and Johnson's theory (1980, 54-55) is the distinction between systematically used metaphors and metaphors that are "dead" (or isolated/unsystematic). One example of a "dead" case is the expression "leg of a table": this conventionally fixed expression can be seen as an isolated case of the metaphor "table is a person." In contrast, the metaphors "time is money" and "love is a journey" employ various aspects of the source domain and are parts of whole metaphorical systems. Metaphors that are close to "dead" or very conventional may yet have significance; they can be extended by using their unused parts and employed, for example, to make jokes or novel metaphors. ${ }^{9}$

\footnotetext{
9 To take an example of our own, the (dead) metaphor of a table as a living thing might be used in a children's riddle like this: "It has four legs, and it never eats but only carries food. What is it?"
} 
Categorizing familial metaphors as nearly "dead," conventional, and novel cases is useful: some expressions may not have a very visible role in the conceptual system whereas others, although conventional, may turn out to be important. ${ }^{10}$ It is necessary to examine whether familial metaphors are consistent, creating a system of interrelated metaphors in the Scrolls, or whether these metaphors serve as more random, single forms of understanding. We will attempt to rank the existing familial metaphors with regards to their possible systematic/ unsystematic character in this text material. In addition, we need to be sensitive to the strength of the rhetorical force of a given metaphor as this varies depending on the context; the word "brother" in Hebrew, for example, ranges from an expression of intimacy to simply denoting "the other."

Metaphor theory shares fundamental aspects with another theoretical framework, the social identity approach. This is a social-psychological theory, based on cognitive studies of human perception. Both the metaphor theory and the social identity approach deal with questions of categorization: human beings understand the world through categories, as kinds of things (such as chair, tree, nation). Human categorization is not based on a fixed set of inherent properties of an object but is context-dependent and based on prototypes, "best" representatives of a category (e.g., a prototypical chair; Lakoff 1987, 9; Hogg and McGarty 1990). Social identity is one's perception of him/herself as a group member and functions similarly: it is the result of comparison in a given context. An individual perceives him/herself as similar to a certain group of people and dissimilar to some other group(s) of people by highlighting similarities and hiding differences; group prototype crystallizes these features (Tajfel 1978; Hogg and Abrams 1988). An individual may hold several social identities simultaneously but often these vary according to the level of abstraction. For example, a person is a European, a Scandinavian, a Southern-Swede, a village-dweller. In a social context where others are urban, a person's identity as rural may become important, whereas at a European congress, his/her nationality comes to the fore (Turner 1999).

${ }^{10}$ Cf. Aasgaard 2004, who employs Lakoff and Johnson's theory about metaphors in his analysis of Christian siblingship in Paul. He (2004, 23-31) remarks that Paul's family metaphors may seem very traditional but can yet turn out to be the "metaphors we live by," structuring the thinking and behavior of Paul and his fellow Christians. 
The categories of identity in the discourses among the various DSS function similarly. They stress similarities to in-group members and differences to out-group members. In addition, categories reflect different levels of abstraction. In the Pesharim, for example, very large categories are present and the language is stereotypical. Insiders are compared to outsiders; they are told who they are by being told who they are not. The collective language creates an image of homogeneous groups. This should not be misunderstood to mean that everyone in the "congregation of the poor" (a concept found in 4QPsalms Pesher ${ }^{\mathrm{a}}$ ) is truly alike or that their identities are all alike. Similarly, large collectives are being compared at a cosmic or ethical level in texts like the discourse on two spirits in $\mathrm{S}$, the description of the eschatological war in the War Scroll (1QM), and the segments in $1 \mathrm{QH}^{\mathrm{a}}$ that emphasize universal dimensions; the "sons/children of light/darkness" or "sons/ children of truth/deceit" are high level descriptions. At a lower level of abstraction, when the insiders themselves are in focus, narrower categories (e.g., priests, Levites, Israelites; sons of Zadok; rabbim) and various functionaries (Examiner, Wisdom teacher, judges) emerge revealing the hierarchical structure of the movement.

Familial language is used at both high and low levels in the Scrolls (e.g., "sons of darkness;" "sons of Zadok"). In light of the social identity perspective, it is necessary to acknowledge that "sons of darkness" cannot be compared to "sons of Zadok;" different levels of abstraction are in use, and the expressions arise from different contexts (e.g., cosmic qualities/origins; assumed genealogy/ancestry). Although both employ the language of son-ship, the underlying metaphors are not the same. Furthermore identity is fluid and context-dependent; familial terminology may seem static and fixed, but in real life familial metaphors could probably serve to comprehend membership in various situations.

These theoretical perspectives serve to structure the data in our discussion below. The Hebrew Bible is clearly one of the most important sources for familial language and metaphors in the sectarian literature, and we will discuss the biblical background as necessary. Furthermore, the Greco-Roman world in antiquity as one definer of the aspects of the source domain (of family and its various members) functioned as a model for the ways in which the target domain (e.g., membership in sect) was being highlighted by familial metaphors. In order to pay due attention to the meaning of familial metaphors in antiquity we will include some comparative material. We will begin with an examina- 
tion of "family," followed by that of "fathers and mothers," "children," and "brothers."

\section{Extended FAmily}

The biblical usage of the concept mispahah has clearly inspired its use in the DSS. In the Hebrew Bible kinship operates on three levels: the tribe (מטה/שבט); the extended family/clan (משפחה); and the bet-av (בית אב), the family as the household, headed by the oldest male in a single lineage (Gottwald 1999, 285; Wright 1992, 761-62; Perdue 1997, 174-75). The mispahah was a sub-unit of the tribe but larger than the single household. ${ }^{11}$ Most of all, it provided protection and subsistence. $^{12}$

In the DSS, the concept mispahah is only found in few places, most notably in the Rule of the Congregation (1QSa) and in D. Its meaning in IQSa is in line with the common practice in the document to apply biblical organizational terms to the community. The list of graduated duties in 1QSa informs us that at the age of twenty a member was to take his/her place among his/her משפחה, "family,"13 joining the holy congregation (1QSa I 9). The second occurrence is in the same context but in the plural: at the age of thirty, one is to take one's place among the chiefs, "in all their mispahot" (I 15). The third occurrence deals with an incompetent who is not to judge or have responsibility in the

11 The mispahah is a "protective association of extended families." In the biblical legislation, the mispahah defined the extent to which a man could be required to act as a "kinsman-redeemer" (Gottwald 1999, 257-67; Wright 1992, 761-62). After the collapse of the tribal organization in $587 \mathrm{BCE}$, the mispahah was replaced by a new structure, the bet-avot, as the basic unit of society. The bet-avot united a number of families that were related, either fictionally or genuinely (Weinberg 1992, 49-61; Collins 1997b, 105; Jenni 1997a, 6).

12 Peskowitz (1993, 28-34) emphasizes the economic nature of Jewish families in Roman Galilee. Families can partly be characterized as working groups; for example, husbands and wives often had a common family trade. Moreover, families living in proximity to each other may have had a common Sabbath meal. See also Blenkinsopp 1997 (53-57). For the Greco-Roman oikos/familia, see Pomeroy 1993; the terminology could be used not only of persons but also of the estate, the property.

${ }^{13}$ For a gender-inclusive reading, see Schuller 1994, 123. Schiffman (1989, 16-18) translates "along with his fam[il]y" and sees two possible meanings: either the initiate remained part of his family until he married, or the (already married or soon-to-be married) initiate brought his wife and children into the community. Schiffman thus holds that women did not become full members in their own right. For an alternative view, see Wassen 2005, 131-56. 
congregation; however, his mispahah shall be inscribed in the register of the army (I 21). There seems to be an attempt to elevate the ideological significance of the mispahah along biblical lines; the mispahah and tribal structure have lost their earlier role, but the community in 1QSa is modeled after the biblical congregation (עדה), tribe (שבט), families/ clans (משפחות), and various commanders and officers of the Hebrew Bible (Metso 2002). The mispahah was traditionally the association of families that supported each other; ideals of mutual support and liability may also lie behind the usage in 1QSa. Perhaps the mispahah had some financial significance in the movement. ${ }^{14}$

The mispahah does not, however, play a significant role in other rule documents. Thus the mispahah is not mentioned at all in $\mathrm{S}$, which accords with the common view that the $\mathrm{S}$ community was made up of celibate members. In contrast, the term appears four times in D, which, like 1QSa, reflects a married community. The Admonition of $\mathrm{D}$ refers to a group of apostates who is excluded together with their mispahot (CD XX 13; see also III 1). In the community organization layer, ${ }^{15}$ the Examiner, mevaqqer, is said to master every language of the mispahot (CD XIV 9-10; however, the reading is not certain); 4QD 11 10, finally, states that God has founded "the nations according to their mispahot, according to their languages, and according to their tribes." It is possible that a mispahah structure existed in the movement, but it is not very clear. ${ }^{16}$ There is little evidence of the mispahah functioning systematically in a metaphorical sense for the movement as a new family. Yet in IQSa and in D, the term evoked biblical ideas about the wilderness community, and thus structured the sect's understanding of itself in terms of the ancient, extended family that provided sustenance and protection. ${ }^{17}$

\footnotetext{
${ }^{14}$ An incompetent person is excluded from the military census but the reason that his family is included may have had economic significance. Gottwald (1999, 315-16) explains the function of the ancient mispahah: "... members had mutual obligations to extend the assistance of their own bet-avot to any needy bet-ab within the mispahah, and to arrange among themselves how they would muster and field a quota of fighting men as required for the tribal and national levy."

${ }^{15}$ For the literary stratification of D, see Hempel (1998).

${ }^{16}$ See Sivertsev 2005, 94-142 who argues that the Dead Sea sect was, at least in its early stages, made up of families and families were its main structural component.

${ }_{17}$ This similar function can be seen in the leadership title ראשי אבות העדה, see below.
} 


\section{FATHER/s AND Mother/s}

In the Greco-Roman household, paterfamilias was the oldest male that headed the familia. ${ }^{18}$ From very early times of Roman society the authority of the paterfamilias was extensive and included the right over life and death of his family members. In comparison, the status of the male head of the Israelite household was similar, although traditionally he would not have power of life and death over his family members (Deut 21:18-21; 22:13-19; see also Wright 1992, 767). In addition, the mother had some authority in a household (Exod 20:12; 21:15, 17). ${ }^{19}$

Parallel to its biblical use, the term אב/אבות carries a wide range of meanings in the DSS. In addition to the meaning of a father in the plain biological sense, the term is used with reference to ancestors,$^{20}$ to a household, bet-av (בית אב), ${ }^{21}$ to God as father, to different leadership titles, and figuratively with respect to a community leader as a father. "Mother," predictably, occurs much less frequently, appearing approximately one fourth as often as "father/s." 2

\section{God's parenthood}

Biological parents are the subject in a hodayah (1QH $\mathrm{QH}^{\mathrm{a}}$ XII 29-31), commonly identified as a hymn of a leader. ${ }^{23}$ Although the text is fragmentary, the section clearly includes praise to God who has been with the speaker from conception.

${ }^{18}$ For the extensive authority of the paterfamilias in Roman law, see Gardner 1991, 6-11. The position of slaves in respect to their master resembled the relationship between the filius of the family and the paterfamilias (Lassen 1997, 109).

${ }^{19}$ Deuteronomic legislation seems to restrict the jurisdiction of the father in favor of local judges and elders (Blenkinsopp 1997, 89).

20 The sins of "the fathers" are highlighted in a few instances (e.g., CD XX 29; 1QS I 25, 26; II 4-11; 4Q434 [4QBarkhi Nafshiª] XII 3), but overwhelmingly אבות carries a positive connotation (e.g., CD VIII 14-18; 1QM XIII 7; XIV 8).

${ }_{21}^{21}$ E.g., CD VII 11 (quotation of Isa 7:17); 4QD 313 ; 11Q19 (11QTemple Scrolla) LVII 16, 19. The plural, "house of their fathers" or "households" (בית אבותם) occurs in 4Q368 (4QapocrPent A) 53.

${ }_{22}$ "Mother" is used in the biological sense in many halakhic contexts (e.g., CD V 9; 4Q251 11 2; 12; 17 4, 5; 4Q396 [4QMMT] 1-2 I 2; 11QT LXIII 13; LXIV 2, 3). In addition, in several instances, "mother" refers to a female animal (e.g., 11QT LII 6; LXV 3, 4).

${ }^{23}$ Several hymns in the Hodayot are written in the first person singular and reflect upon the experiences of a leader (1QH $\mathrm{QH}^{\mathrm{a}}$ X-19; XII 5-XIII 4; XIII 5-19; XIII 20-XV 5; XV 6-25; XVI 4-XVII 37). 
For You from my father have known me, from the womb [You have set me apart, and from the belly of] my mother You have rendered good to me. From the breasts of she who conceived me, your compassion has been mine. ${ }^{24}$

At the same time, the biological father and mother are depicted in negative terms later in the same hymn in an allusion to $\mathrm{Ps}_{\mathrm{s}}$ 27:10 $\left(1 \mathrm{QH}^{\mathrm{a}}\right.$ XVII 35): $:^{25}$

For my father did not know me, and my mother abandoned me to you.

Has the individual experienced lack of protection from the parents? Or have the parents given up their child? Regardless of any possible historical background, the point of the biblical psalm and the hodayah is that the speaker belongs to God; indeed the parenthood of God is the only protection the individual needs, as the hymn continues $\left(1 \mathrm{QH}^{\mathrm{a}}\right.$ XVII 35b-36):

For you are a father to all the [son]s of your truth. You rejoice in them, like her who loves her child, and like a wet-nurse you take care of all your creatures on (your) lap.

In this case, God is portrayed as a father ${ }^{26}$ as well as a mother. Newsom (2004, 345-46) shows that those hymns that represent the character of a community leader articulate a leadership myth of the community and are written to provide a model for community leaders first, but also for the sectarians in general. She states, "Finally, the leader offers himself as a model for the formation of a sectarian character. His presentation of himself - his experiences, actions, and sentiments - models the character implied by the teachings of the sect." If this is the case, then the attitude to one's family that emerges in $1 \mathrm{QH}^{\mathrm{a}} \mathrm{XVII}$ for the sectarians to emulate is to give up attachments to one's biological parents in favor of relying completely on God as well as to submit oneself fully to God's will. In no uncertain terms the speaker makes clear, even with

\footnotetext{
${ }^{24}$ The translation follows that of Abegg et al. (Parry and Tov 2005, vol. 5).

${ }^{25}$ All the translations from this point onwards follow García Martínez and Tigchelaar (1997-1998) with minor alterations unless otherwise stated.

${ }^{26}$ Similarly, 4Q382 (4Qpap Paraphrase of Kings) 104 3: "You will rule over them and be for them a father." Cf. 4Q372 (4QNarrative and Poetic Composition ${ }^{\mathrm{b}}$ ) 1 16: "And he said: 'My father and my God, do not abandon me..."”
} 
Ps 27:10 as authority, that no parent is needed except for God. ${ }^{27}$ The metaphor of God as parent is very biblical but set in a new context; as such, it highlights God's care and love.

In contrast to this sentiment, the wisdom tradition in 4Q416 (4QInstruction $^{b}$ ) refers to both parents several times in the tradition of the commandment to honor one's father and mother (Exod 20:12). The author admonishes the reader to honor and serve both parents submissively, reaffirming the social hierarchy of the day, namely that of parents over children and husbands over wives. Still the authority of both parents is noteworthy:

Honor your father in your poverty, and your mother in your low estate. For as God is to a human so is his own father; and as the Lord is to a person so is his mother. For they are the womb that was pregnant with you. And just as He set them in authority over you and fashioned (you) according to the spirit, so serve you them (4Q416 2 III 15-16). ${ }^{28}$

Again, the relationship between parents and child is compared to that of God and humans, but the metaphor aims at strengthening the reader's willingness to submit him/herself to the authority, not only of God, but also of his/her biological parents - unlike in the hodayah we studied above. Parental metaphors also mark leadership status and honor, as we will explore below.

\section{Leadership as Parenthood}

The community leader takes on the role of a nurturing parent in $1 \mathrm{QH}^{\mathrm{a}}$ XV 6-25 in that God has made him a father and a nurse (nursing mother?):

You have made me a father for the sons of kindness, like a wet-nurse to the men of portent; they open their mouth like a child on the breast of its mother,] like a suckling child in the lap of its wet-nurse $\left(1 \mathrm{QH}^{\mathrm{a}}\right.$ XV 20-22).

As a whole, this hodayah encourages the sectarians to submit themselves to their leader as children to their parents and rely on their leader for protection and instruction. In light of $1 \mathrm{QH}^{\mathrm{a}} \mathrm{XVII}$ 29-36, which puts

\footnotetext{
27 A similar negative attitude toward biological parents is found in 4Q175 (4QTestimonia) $15-16$ in a quotation from Deuteronomy 33:8-11 in which Levi rejects his father and mother and children in favor of God.

${ }_{28}$ The translation is based on that by Strugnell and Harrington (in Parry and Tov 2004, vol. 4).
} 
forth detachment from one's biological parents as ideal, the presentation of the leader as a parent in $1 \mathrm{QH}^{\mathrm{a}} \mathrm{XV}$ becomes particularly poignant: he can help fill the void left from the absense of biological parents. It is also worth reflecting on the mirror images of the leader and God in their nurturing capacities, which Newsom $(2004,298)$ highlights. Since the community leader is portrayed as having the caring and protecting characters of God, this evidently further strengthens the parental role of the leader as one to whom affection and submission is the only natural attitude of the sectarians, his children.

Parental terms are also used for officials to indicate status and position within the group. ${ }^{29}$ In 1QSa and in 1QM, אבות appears several times as part of the title ראשי אבות העדה, "heads of the fathers (or households/clans) of the congregation." ${ }^{30}$ The use of the title is part of the general preference for employing biblical wilderness terminology. ${ }^{31}$ No form of the title appears in the two main rules, $\mathrm{S}$ and D, unless "the Fathers" is a short form of the title (see below). Perhaps the function of the to preserve order in the biblical tradition gives a hint of the responsibilities of these leaders. ${ }^{32}$ Yet, we know little of their specific activities. ${ }^{33}$ The use of the title can be seen as metaphorical

${ }^{29}$ In the Hebrew Bible, metaphorical parent language is found in honorary titles: father is the title for a king/master (2 Kgs 5:13), an officeholder (Isa 22:20-21), a prophet/teacher (2 Kgs 13:14; 2:12), a priest (Judg 17:10), a benefactor (Job 29:16), and possibly the founder of a professional guild (1 Chr 4:14).

${ }^{30}$ See 1QSa I 16, 23-25, II 16; 1QM II 1, 3, 7; III 3-4. אבות in these cases probably carries the meaning of "clans" or "households:" ראשי אבות is used of leaders of clans or households in the Israelite community in Exod 6:25; Num 31:26, Josh 14:1; 19:51 (they are in charge of dividing the booty justly, and parceling out the land to the tribes). There are two references to אבות העדה in 1QM II 1, 3, but also in these cases the full title ראשי אבות העדה may be assumed (Yadin 1962, 263). The title occurs also in 4Q365 (4QReworked Pentateuch ${ }^{c}$ ) 26a-b 8, in 4Q299 (4QMysteries ${ }^{\mathrm{a}}$ ) 763 , and in the fragmentary 4Q423 (4QInstruction") 52 (כל ר] וש אבות]) in a section recalling God's work in the past.

31 The key name for the community in LQSa is עדה, which is the common term for the entire Israelite congregation in the wilderness, the camp in P. The division into 1000's, 100's, 50's and 10's parallels that of Israel's army (Deut 1:15, cf. 1QS II 21-22; CD XIII 1-2).

${ }^{32}$ In 1QSa, ראשי אבות העדה have a leadership role alongside the priests. In 1QM, their number is 52 (1QM II 1, par. 4Q494), and apparently they rank just after the chief priests, chiefs of the Levites, chiefs of their divisions, and chiefs of their tribes (II $1-3)$. Their military role in the final war is indicated by 1 QM III $3-4$, which defines the order of the trumpets in war.

${ }^{33}$ Both 1QSa and 1QM have an eschatological orientation, 1QM more so than 1QSa. It is reasonable to assume that there is some degree of correspondence between the officials listed in the texts and the leadership roles in the actual communities. Nevertheless, some elements appear to reflect expectations for the future, most obvi- 
familial language; at the same time the expression is clearly adopted from biblical terminology in these documents and conveys the idea of orderly care in the community.

In D, "the Fathers" and "the Mothers" appear as titles of honor in the context of the penal code:

[One who murm] urs against the Fathers [shall be expelled] from the congregation and not return; [if] it is against against the Mothers he shall be penalized for te[n] days, for the M[o]thers do not have rwgmh in the midst of [the congregation] $\left(4 \mathrm{QD}^{\mathrm{e}} 7 \mathrm{I} 13 \mathrm{~b}-15\right) .{ }^{34}$

The reference in D to the groups of Fathers and Mothers is somewhat of an enigma. Neither the Fathers nor the Mothers appear as titles elsewhere, although it is possible that "the Fathers" is a short form of "the fathers of the congregation." This is also the only instance where women (whether in the singular or the plural) are mentioned in a possible position of leadership in any of the rules..$^{35}$ Finally it is unclear to what rwqmh refers. ${ }^{36}$ Regardless of these anomalies, it is significant that there were groups of women and men, who were called Mothers and Fathers and who deserved respect in the community ${ }^{37}$ Although the Fathers evidently ranked higher than the Mothers, as the great disparity in penalties indicates, the authority of neither group was to be questioned.

The portrayal of the key leader in $\mathrm{D}$, the mevaqqer, is cloaked in parental terms (CD XIII 7-16). The mevaqqer is an eminent teacher of wisdom who instructs the Many about God's deeds in the world throughout history (CD XIII 7-8). CD XIII 9-10 refers to the mevaqqer as a father and ascribes characteristics to him recalling those of a divine protector:

Let him love them as a father does his children (כאב לבניו) and watch over them in their distress as a shepherd for his flock. Let him loosen

\footnotetext{
ously the banquet in which the Messiah participates (1QSa II 11-22). Hempel's (1996) distinction between an early rule intended for an actual community and later additions of messianic elements remains plausible.

34 Translation based on Baumgarten (in Parry and Tov 2004, vol. 1).

${ }^{35}$ For references to female elders, זקנות, see 4Q502 (4QpapRitual of Marriage) 24 4; 19 2, and Crawford 2003.

${ }^{36}$ See Elwolde 2000; Brooke 2003b; Wassen 2005 (189-97).

37 Since Mothers and Fathers are in the plural, it is unlikely that biological parents are meant. Collins (1997b, 134-35) notes that the Therapeutae, in Philo's account, included celibate women who took part in their ceremonies and that the young men who served the meal behaved like "sons to their real fathers and mothers."
} 
all the chains that bind them so that there shall be none deprived and crushed in his congregation. ${ }^{38}$

The language of a loving father, a shepherd, and of loosening of chains belongs to the traditional imagery associated with God. In this case, parallel to $1 \mathrm{QH}^{\mathrm{a}} \mathrm{XV}$ (see above), it is the nurturing features of God as a parent that are underlined. Also like $1 \mathrm{QH}^{\mathrm{a}} \mathrm{XV}$ the sectarians are encouraged to view their leader in extraordinary terms, as a mirror image of God. In light of the extensive rights of the leader that follows in CD XIII, the evocative language is probably intended to legitimize this power; by hiding the image of a dominating, powerful father figure and instead highlighting the nurturing aspects of the father, the texts aims at building trust in the leader. The discourse thus prepares the reader to be accepting of the extensive power of the mevaqqer which is outlined in the subsequent lines; the mevaqqer is in charge of the examination of potential new members (XIII 12-13), of supervising the business transactions of members (CD XIII 15-16/4QD 9 III 1-4) as well as of marriage and divorce (4QD 9 III 4-6). ${ }^{39}$ In $\mathrm{D}$, the mevaqqer has evidently taken over many of the responsibilities and rights that traditionally belonged to the biological father (Wassen 2005, 160-64, 202-5). CD XIII 13 further emphasizes the hierarchical power relation between the regular members and the mevaqqer by stating that the "sons/ residents of the camp" may not bring anyone into the congregation "except by the word of the mevaqqer of the camp."

It is worth noting that the mevaqqer is never represented in fatherly terms or with characteristics reminiscent of God in S. Consistent with this circumstance are the different levels of authority of the mevaqqer in the two documents in relation to accepting new members. In $\mathrm{S}$ the mevaqqer is subordinate to the Many (1QS VI 11-23) while the reverse is the case in D (CD XV 7-15) (Metso 2002, 441). Instead, it is the maskil in $\mathrm{S}$ who, although not called a father, comes close to a father figure. The description of the maskil is reminiscent of that of the mevaqqer: he knows the correct interpretation of Torah and has gained astonishing insights from God into eternal things, "mysteries of wonder and truth"

\footnotetext{
38 Translation based on Baumgarten and Schwartz 1995.

${ }^{39}$ Murphy (2002) suggests that "loosening of chains" had financial meaning; perhaps slaves and persons in debt were redeemed by the sect. The mevaqqer is also responsible for some kind of instruction to the children within the community: "He shall instruct their sons [and daughters] and their children [in a spir]it of hu[mi]lity and lov[ing kindness]" (4QD' 9 III 6-7).
} 
(1QS IX 18; cf. CD XIII 8), in order to instruct the community in the will of God. Both characters also share an elevated position in which they resemble God. ${ }^{40}$ According to the discourse on the two spirits (1QS III 13-IV 26), the maskil is to teach all the children, "the sons of light" (III 13). The text places him in a unique, elevated position as a teacher, clearly above the "sons." Similarly, in the extensive section devoted to the statutes concerning the maskil at the end of the document (1QS IX 12-X 5), his role is outlined in relation to the "children:" the maskil "shall separate and weigh the children of righteousness ${ }^{41}$ according to their spirits" (IX 14). Yet, the community members are only once called "children" in the section amongst other names that express the identity of the group, ${ }^{42}$ and the expression emphasizes the righteous quality of the members more than their identity as children (see below). Hence, the metaphor of the maskil as a father is not nearly as pronounced as in the case of the mevaqqer in $\mathrm{D}$.

\section{Children}

The term בנים/בן appears frequently in the Scrolls and most often it expresses biological kinship, both distant (as descendants e.g., CD II 19; III 1, 4, 5, 9) and near relations (e.g., "son of X" in CD IV 14-15; VII 10; VIII 20). Duties of the mevaqqer include instructing "their children" and dealing with modesty and love with "their small children" (CD XIII 17-18 // 4QD 9 III 6-7)-biological children of the camp-members are probably meant here, too. However, this is also one example of the biological parent-child relationship being supplemented or replaced by the leader-member relationship.

The term בנים is also used in its extended meaning of followers or disciples. ${ }^{43}$ Although this usage can be classified as metaphorical it is still rather conventional: the metaphor is found mostly in forms of address

\footnotetext{
40 Not only does the maskil know the spirits of the humans (IX 14) and portions out his love and hate accordingly (IX 14, 21), he is also capable of having "eternal hatred" for the "men of the pit" (IX 22). God's will and that of the maskil are inseparable (IX 23-26). S also highlights a non-familial metaphor of God as a judge.

${ }^{41}$ Since the definite article is used, הצדוק, the text does not refer to the Sons of Zadok, i.e., the priests.

42 E.g., "chosen ones of the end time" (IX 14), "the chosen of the way," (IX 17-18), and "the men of the community," or simply "they/them" (e.g., IX 18).

43 In the Hebrew Bible, disciples of prophets and wisdom teachers are addressed as sons (1 Sam 3:6; Prov 1:8; see Keener 2000, 356-57; Jenni 1997a, 4-6).
} 
and is not employed in other areas of language. The beginning of the Admonition of $\mathrm{D}$ is a sermon in which the speaker exhorts the listeners to pay attention to his message (4Q266 la-b 1-21; 2 i 1-6; CD I 1-II 17). By calling on the listeners - "listen, all who know righteousness" (CD I 1), "listen, all who enter the covenant" (II 2), and "listen, children" (II 14) - the speaker takes on an explicitly fatherly role. Most translators translate "sons," but "children" is perhaps preferable if we think that this kind of teaching would take place in the covenant renewal ceremony where families were present (Knibb 1987, 14; Falk 1998, 236ff., Wassen 2005, 26-27). The way of addressing listeners as sons/ children is typical to wisdom traditions. For example, 4Q185 (4QSapiential Work) exhorts: "Listen to me, children..." (1-2 II 3; cf. 1-2 I 9 "human children"), and 4Q298 (4QCryptic A) I 1 includes words of the maskil "to all sons/children of dawn." In 4Q417 (4QInstruction"), בן בן מבין בן "understanding son" (2 I 18), and adressee is called משכיל, "wise son" (2 I 25).

The analysis of "sons" is complicated by the fact that, in Hebrew syntax, בץ one of those nouns that often expresses the possessor of a quality in a genitive construct (instead of an adjectival expression) or an individual that belongs to a class of beings. ${ }^{45}$ Thus may denote a quality or a class rather than biological or familial relationship. This usage indicates that "son/s" often can be considered a "dead" metaphor, where the source domain is no longer recognized or plays no part in the expression. Examples in the DSS are בני ישראל as "Israelites" (CD IV 1), בן הנכר as "a foreigner" (CD XI 2), בני כל כי בנר as "birds" (1QM X 14), בני האדם as "humans" (CD XII 4; 1QS XI 20; 1QH 1QS XI 6, 15 without the article), and בני איש as "humans" (1QS IV 15, 20, 26; 1QM XI 14). Members of the same camp are בני המחנה בני תבל (CD XIII 13). People who live on earth (i.e., any people) are (CD XX 34), and conversely, בני שמים (1QS IV 22; XI 8; 1QH XI 22) are heavenly beings.

Commonly, genitives with a proper noun do not convey real genealogical origins; rather they describe ideological/spiritual origins. For

\footnotetext{
${ }_{44}$ But here + genitive may also be an adjectival expression, see below. Kühlewein (1997, 242) translates בן משכיל 10:5 as "clever."

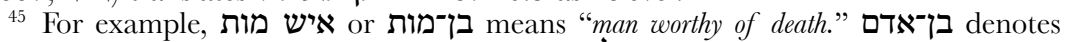
"an individual of the human species, a human," and בני אלים "a denotes "divine beings." Age is typically expressed in this way: בן־מאת שנה means "a hundred years old" (cf. CD X 6-7). However, בני הנביאים are "disciples of prophets, not prophets properly speaking" (Joüon and Muraoka 2000, 468-69).
} 
example, בני צדוק (CD III 21-IV 1; IV 3) denotes "Zadokites," members of the Zadok-group, rather than descendants of the high priest Zadok. In Ezekiel 44, which is the source for the expression in CD IV, the designation בני צדוק probably refers to the Jerusalem priesthood. ${ }^{46}$ In the same quotation (Ezek 44:15 in CD IV 1) בני ישראל denotes "Israelites" that went astray. ${ }^{47}$ Later on, in a different context (CD VII 21) and based on different scriptural allusions (Num 24:17) "children of Seth" or "Sethians," is the expression for a group that is viewed negatively. The metaphoric nature of these expressions is the result of using scriptural labels (the proper nouns) to make certain points, rather than an intent of expressing familial relationships of son-ship. ${ }^{48}$

The phrase בני השחת in CD VI 15 (possibly CD XIII 14) is yet בנים another example of a genitive construction in which the noun conveys the quality of the group; the covenant members are to separate themselves from these "children of the pit." The expression mediates the nature of this group: they deserve the pit, the destruction, or they bring along the destruction. Similarly the famous designations בני אור, "sons/children of light," and בני חושך, "sons/children of darkness,"49 express the nature of these groups: they reflect or follow light/darkness, or they belong to the cosmic sphere of light/darkness. ${ }^{50}$ Likewise, the

${ }_{46}$ Baumgarten (1979) argues that בני צדוק was not a genealogical category; Zadokite ancestry was not the main issue. In Ezek 44, בני צדוקי belong to the class of Levite-priests. In CD, however, there are three separate groups: "priests," "Levites," and "Zadokites" do not stand in apposition to each other, but are distinguished by $w^{e}$-conjunctions and receive their own characterizations, as if they were qualitatively (or chronologically) distinct. On the other hand, S, Sa, and $\mathrm{Sb}$ define the "sons of Zadok/Zadokites" as "priests" (1QS V 2, 9; 1QSa I 2, 24; II 3; 1QSb III 22). Other designations for priests in these documents are בני אהרון, "sons of Aaron/Aaronites" (1QS V 21; IX 7; 1QSa I 15, 23), and בני לוי, "sons of Levi/Levites" in 1QSa I 22. Note that biological sons of Aaron are mentioned in 1QM XVII 2.

בני עמך, "Israelites" can also be covenanters: CD XIV 4, 5; 1QS I 23. Similarly, in CD IX 2 denotes members of the same people, here in a neutral sense, quoting Lev 19:18.

${ }^{48}$ The War Scroll uses scriptural tribal names for both the Army of Light (e.g., I 2, "children of Levi, children of Judah, and children of Benjamin"), and the Army of Darkness (e.g. I 1, "band of Edom and of Moab, and children of Ammon").

${ }^{49}$ E.g., 1QS I 9, 10; II 16; III 13, 24, 25; 4QD ${ }^{\text {a }}$ la-b 1; 1QM I 1, 7, 9, 10, 11, 13, 16; III 6, 9; XIII 16; XIV 17; XVI 11; 4Q177 II 7; IV 16; 4Q510 I [7].

${ }_{50}$ The treatise on the two spirits is explicit about the cosmic dimension. 1QS III 20 explains: "In the hand of the Prince of Light is dominion over all the בני צדק; they walk on paths of light." Respectively, "in the hand of the Angel of Darkness is dominion over בני עול; they walk on paths of darkness" (1QS III 21). It is noteworthy that the treatise does not use exclusively the designations "children of light/darkness" but emphasizes the role of deception ("children of deceit," "spirit of deceit") in the 
expression בני אמת, "sons/children of truth," (1QS IV 5, 6) communicates the idea of truthful ones (cf. בני אמת in 4QD 11 7; 1QM XVII 8; 1QH" [XIV 29]), בני סוד עולמים (members/children of the everlasting counsel," (1QS II 25) are individuals who have access to counsel/who belong to a circle of confidants. The use of בנים/בן in these cases serves to highlight one quality over another more than expressing a metaphorical son-ship. This is shown by the use of similar expressions with the alternative noun איש or or אנשי

\section{Membership as Child Relationship}

In light of the semantic range of son-ship terminology, the question is whether the language of "sons/children" ever refers to a metaphoric child-parent relationship indicating that membership was structured in terms of such relationship, and if yes, in which cases? In general, the terminology of sons/children has not been purposely chosen to emphasize the insiders' tight association as children in one family since it is used for both insiders and outsiders as in the case of "sons of light" versus the "sons of darkness." In comparison to the brotherhood language in the DSS, the son-ship language is much more frequent. Even though the son-ship metaphor is sometimes almost "dead" or very conventional, as we have explored above, in our opinion some metaphoric cases in the DSS show that it still had significance in the conceptual world of the members.

cosmic history. A similar expression, בני עולה, "children of injustice," is used in 1QH XIII 8, and in 4Q418 (4QInstruction ${ }^{d}$ ) 69 II 8 and 4Q511 (4QSongs of the Sage ${ }^{\mathrm{b}}$ ) I 8 of people who do not last (cf. 2 Sam 7:10).

${ }^{51}$ It is not clear if the phrase בן אמתכה in 1QS XI 16 and in 1QH ${ }^{a}$ VIII 26 should be interpreted as "son of your truth," or "son of your maidservant." Parallelism to a "servant" in a nearby context speaks for the latter, cf. Ps 86:16. However, בני אמתכה "che " in $1 \mathrm{QH}^{\mathrm{a}} \mathrm{XV} 29$; XVII [35]; XVIII 27 are almost certainly "children of your truth." It is noteworthy that a feminine expression also exists: בת אמת, "daughter of truth," occurs in a fragmentary context in 4Q502 (4QRitual of Marriage) 1-3 6 (for a discussion of the references to women in 4Q502, see Crawford 2003).

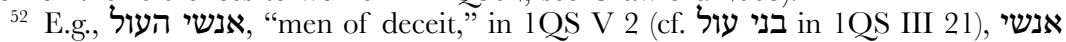

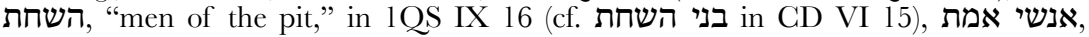
"men of truth," in 1QH 2 (cf. אני אמת in 1QS IV 5), אנשי אשמה, "men of guilt," in 1QH" XIV 18 (cf. בני אשמה in 1QH' XIII 7), and אנשי בריתם, "men of their covenant," in 1QS V 9 (cf. בני בריתו in 1QM XVII 8). Sometimes the different context in different documents may explain the variation. For example, concerning the "children of his covenant" in 1QM, the context is that of a speech by the high priest to the army, and the listeners are addressed as "you, sons of his covenant." 
One such case is found in the discourse on two spirits (1QS III 13-IV 26): it uses almost exclusively son-ship language for the members which may indicate that the metaphor of son-ship is "alive." No brotherhood language is used. Moreover the expressions "sons/children of light" and "sons/children of darkness" are fixed formulations: there are no occurrences of alternative terms such as "men of light/darkness" (the same applies to "sons/children of righteousness") in any of the DSS. Hence here the language of sons/children is likely to evoke the idea of God as the Father of the household; although the expression denotes the quality of the sons as belonging to the light, it also expresses the metaphorical sense of divine son-ship. Nevertheless this is an all-inclusive image of God's household: the adversaries ("sons/children of darkness") have their role in it for the time being (1QS IV 15ff., cf. I 9-11).53

Metaphorical son-ship language occurs in $\mathrm{D}$ as well. The first preserved fragment of D addresses the "sons/children of light" $\left(4 \mathrm{QD}^{\mathrm{a}}\right.$ $1 \mathrm{a}-\mathrm{b} 1)$. Later we learn that those who despise the regulations shall not be considered among the "sons/children of his truth" $\left(4 \mathrm{QD}^{\mathrm{a}} 11\right.$ 7) - this recalls the cosmic language of the discourse of the two spirits in $1 \mathrm{QS}$ and of the eschatological war in $1 \mathrm{QM}$ and $1 \mathrm{QH}^{\mathrm{a}}$. Previously we noted that parent metaphors were used of leader figures in D. Apparently then there is a dual kind of son-ship in D: by being children of their superiors in the community, members are children of God. This imagery thereby stresses the parental role of the leaders alongside (or representing) God. It should be noted however that familial language of son-ship is not used frequently throughout the whole document and in that sense is not a strong image.

In the Hodayot, as we have seen, there are passages where familial metaphors play an important role, for example in the "Teacher hymn" in column XV, "You have made me a father for the sons of kindness" $\left(1 \mathrm{QH}^{\mathrm{a}}\right.$ XV 20). This hodayah articulates the experiences of a sometimes fatherly leader figure who is sustained by God and who then can sustain and

${ }^{53}$ In spite of the language of "sons/children" in IQS III 13-IV 26, there is no explicit father; the supernatural leaders, the Prince of Light and the Angel of Darkness, are not presented using parental imagery. Nevertheless, implicitly God is the father figure in the passage as he has created the spirits and, with the Angel of Truth, he helps the children of light. Furthermore, it should be noted that the teaching on the two spirits is presented as the actual teaching of the maskil. Hence, the discourse aims at strengthening the position of the leader/maskil in the community and the submissiveness of the children towards him as he takes on the role of God's intermediary (only he knows their true nature; 1QS III 13-14). 
guide others. As he is dependent on God, the "children" are dependent on him and can rely on him. But as we saw there is also a more direct relationship between "children" and God which creates a dual kind of son-ship also in 1QH': "You (i.e., God) are father to all the [son]s of your truth" (1QH $\left.\mathrm{QH}^{\mathrm{a}} \mathrm{XVII} 35\right){ }^{54}$ God's active role and humans' total dependence on him and his mercy are repeatedly stressed in $1 \mathrm{QH}^{\mathrm{a}}$ also with the language of son-ship (e.g., 1QH $\mathrm{QHI}^{\mathrm{a}}$ 31-33).

In these and other cases where the metaphoric familial connotation is likely we can think of three primary aspects utilized of the source domain, son-ship. First the metaphor can communicate the idea of quality or origin, the stemming from something, as children stem from earlier generations. Son-ship can also express submission with respect to one's superiors or to God as we saw in the context of parental metaphors. In addition sometimes son-ship may convey the idea of honor: being a child of one high in status is honorable. Thus, son-ship terminology can stress the unity of members through common, fictional origins, through common obligations, or common honorable status. At a high level of abstraction son-ship metaphors, such as "sons of truth," include all members and highlight their common features as truthful ones while the differences between members are minimal.

However, although son-ship stresses unity among the members, it is yet obvious from many passages that this is not a family of equals; at a lower level of abstraction their differences are apparent: even the "sons of light" have different portions of light (1QS I 9-10) and son-ship is hierarchical in this respect. Similarly, 1QS II 23-25 speaks of the "sons/children" of the community and also spells out the hierarchical nature of the group:

... so that each Israelite may know his standing in God's yahad in conformity with an eternal plan. No-one shall move down from his rank nor move up from the place of his lot. For all shall be in the yahad of truth, of proper meekness, of compassionate love and upright purpose, בני סוד) עולמים) (1QS II 22-25)..$^{55}$

${ }^{54}$ Also 1QH ${ }^{a}$ XV 29-31. Another text, 4Q504 (4QWords of Luminaries), stresses the relationship between God and Israel as one between a parent and children: "You have established us your sons/children in the sight of all the peoples. For you called [1] srael 'my son, my first-born' and have corrected us as one corrects his son" (4Q504 1-2 III 5-7).

${ }^{55}$ García Martínez and Tigchelaar (1997-1998) translate "associates of the everlasting society." 
Here "sons/children" are bound together in emotional, spiritual and ethical bonds, but this fellowship is manifested in the system where each member knows his place and is dependent on superiors. Although the language does not draw heavily from family imagery (בני סוד עולמים could be understood as "members of the eternal counsel"), it nevertheless carries the potential for listeners to identify with God's household where righteousness prevails and everything is in order.

Another kind of child-metaphor is found in another hodayah, $1 \mathrm{QH}^{\mathrm{a}}$ XI 1-18. Here the metaphor of giving birth is used:

As children come to the womb opening of death, so she who is pregnant with a manchild suffers in her pain pangs. ${ }^{56}$

Unlike in $1 \mathrm{QH}^{\mathrm{a}} \mathrm{XV}$ 6-25 where the speaker has a nurturing role, here the emphasis is on the pain and threat of death in delivering a child. It has been suggested that this hodayah describes the birthing of the community by its leader (see Newsom 2004, 242). If so the hymn puts further stress on the leader-member relationship as a parent-child relationship. On the other hand, the hodayah also describes another woman who is pregnant with nothingness (XI 12). The birth pains are similar for both women but the outcome is different (Newsom 2004, 251-52). Hughes proposes that the key contrast is that between fruitful and unfruitful suffering that belongs to the end-time scenario. The speaker understands his own distress in light of the suffering preceding God's final intervention (Hughes 2006, 191-92). From this perspective the child-parent relationship is not essential here; instead what is highlighted in the metaphor is the present suffering of an individual and the hope for subsequent deliverance and joy which is placed within an eschatological framework.

Expressions such as "sons/children of Adam" and other categories with "sons/children" are one way of creating a universal, high-level dimension in the Hodayot. The document is unique in having the speaker identify with fragile and sinful humankind; yet he is set apart from the rest of the "sons/children of Adam" as God does wonders to him and reveals his secrets to him (1QH $\mathrm{QH}^{\mathrm{a}} \mathrm{XII}$ 15-16; XIX 3-10). Not all the "sons/children of Adam," God's creation, have a future. Various descriptions are used for those who will face destruction in the end: they are "sons/children of guilt" (XIII 7; XIV 30; XV 11, cf. "men

\footnotetext{
56 Translation by Newsom 2004, 243.
} 
of guilt" in XIV 18-19), "sons/children of injustice" (XIII 8; XIV [18]), and "sons/children of destruction" (XIII 25). Newsom (2004, $232,240)$ has shown that the painful contradiction between human nothingness and the possession of divine knowledge remains partly unsolved. The speaker is between conflicting powerful forces, God and the wicked, or even more, he feels this contradiction within himself; what distinguishes himself from the wicked is not always obvious in his deeds and his being. ${ }^{57}$

The universalism of $1 \mathrm{QH}^{\mathrm{a}}$ then is one reason that the son-ship language is not being used for insiders exclusively, but also for outsiders. $1 \mathrm{QH}^{\mathrm{a}}$ also uses servant terminology (e.g., $1 \mathrm{QH}^{\mathrm{a}} \mathrm{IV} 11,23,25,26$; V 24; VI 8), language of poverty (e.g., VI 3-4; XI 25; XIII 13), and the imagery of clay vessels (e.g., XII 29; XXII 11) to emphasize the low position of humanity under God. It is the loneliness that seems to characterize the hymnist rather than a safe and secure place in God's household. The singers/listeners of $1 \mathrm{QH}^{\mathrm{a}}$ learn to identify themselves with this humble and lowly figure of the hymns and see their place in the world not subordinate to their family nor even the community but to God and his guidance channeled through the community superiors.

\section{BROTHERS}

In comparison to father-son terminology brother metaphors carry the potential to convey more egalitarian notions. Before we turn to the DSS we will briefly examine ideas both concerning the source domain of the brotherhood metaphor; that is (biological) brotherhood in antiquity as well as metaphorical language of brothers that can provide some insights into what the term meant in antiquity. The most important Greek source for considering brotherhood is Plutarch's work "On brotherly love." ${ }^{58}$ Plutarch uses the metaphor of the human body to argue that, although brothers have different roles, they should work together in harmony. The harmony of brothers is the basis of a healthy family life

${ }^{57}$ In comparison to biblical psalms, human conflict (speaker versus enemies) is transferred into a cosmic conflict (God versus enemies), where God acts and the speaker is passive (Newsom 2004, 236-37). Only God's election and divine knowledge of human beings distinguish the author and his group from those under judgment.

${ }_{58}$ Plutarch (c. 45-120 CE) was a Platonist philosopher and biographer who studied in Athens, taught in Rome and spent most of his life in Chaironeia, Greece. See Burke 2003. 
(Frat. Amor. 2/479A). However, because of age, nature, or social status, hierarchies also exist among brothers: "... it is impossible for them to be on an equal footing in all respects" (Frat. Amor. 12/484C). ${ }^{59}$ Envy particularly was a threat to the unity of brothers; if it could not be avoided, hostility was to be channeled outside the family (Frat. Amor. 14/485E). Aasgaard $(1998,103)$ explains that although siblings were on more or less same level in the hierarchy of the ancient family, it is anachronistic and misleading to speak of sibling-ship as an egalitarian relationship: "It is more appropriate to view it from the perspective of unity and harmony, and within a strongly hierarchical system" (see also Aasgaard 2005).

The early church extensively incorporated household terminology in the construction of its identity and organization. Though employing a range of familial metaphors, Paul is particularly fond of the term "brothers." Paul consistently addresses his readers as "brothers" he affectionately encourages them to show "brotherly love," $\varphi \imath \lambda \alpha \delta \varepsilon \lambda \varphi{ }^{\prime} \alpha$, for one another (Rom 12:10). Still he asserts his authority over the congregation by employing other kinship terms such as a father addressing his children (e.g., 1 Thess 2:7-12). ${ }^{61}$ Although we cannot assume full equality between brothers, their relationship in the ancient household was fairly equal in comparison to that between the householder and other family members. Given the complexity of the brother terminology, it is important that family terms in the DSS are carefully investigated in each instance and within the context of the whole discourse in order to determine their proper connotations.

59 For a comparison between Paul and Plutarch, see Aasgaard 1997 and Burke 2003. Both Paul and Plutarch acknowledge differences among brothers, and, consequently, a superior/inferior arrangement between brothers. Both also view brother relations as distinct from all other relationships. Aasgaard notes that Paul rarely employs friendship language concerning church members.

${ }^{60}$ E.g., 1 Cor 2:1; 3:1; 14:6, 20, 15:1; Rom 16:17. Altogether words related to brother (adelph-) appear over 100 times in Paul's letters. He calls Phoebe a sister (Rom

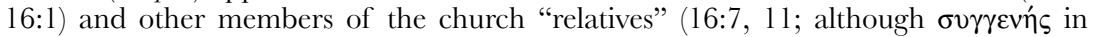
this instance can simply mean a fellow Jew).

${ }_{61}$ Aasgaard $(1997,176)$ observes that Paul refers to his co-Christians as his brothers and thus seems to figure himself as a brother, but he never calls himself that. "Rather, when he describes his role in terms of kinship, he is a "father" (1 Cor 4:15), an "old man" (Phlm 9), even a "mother/nurse" (1 Thess 2:7). When he wants to imply distinctions, he does not do it within the brother concept, but by abandoning it, e.g. by using other kinship structures." 


\section{Membership as Brotherhood?}

The Hebrew אח אח has a range of meanings, from the narrow "biological brother," "half-brother," or "kinsman," to "fellow countryman," or "companion," or simply "the other" (Jenni 1997b, 73-77). ${ }^{62}$ Consequently brotherhood language is used in the Hebrew Bible straightforwardly for (Levite/priestly) colleagues, for fellow soldiers, and for stressing the (real or imagined) tribal bond (see Jenni 1997b, 74-76). ${ }^{63}$ Frequently it occurs in courtly address in speech/correspondence and in diplomacy. ${ }^{64}$ Sibling terminology may also express solidarity (Job 17:14; 30:29) and similarity (Prov 18:9). In Deuteronomy, אחיך, "your brother," becomes the main expression for one's fellow whom one is obliged to love (e.g., Deut 15:9, 11;22:1); it also distinguishes the Israelites from foreigners (Deut 17:15; 23:20-21).

In the majority of the occurrences in the $\operatorname{DSS}^{65}$ אח has a biological meaning ("brother, kin"): this appears in biblical quotations and in rewritten scriptural genres (e.g., Jubilees, Temple Scroll) especially. ${ }^{66}$ Its usage as a rhetorical address is found at least in one parabiblical text, 4Q378 (4QApocryphon of Joshua $\left.{ }^{a}\right) 6$ I 5, 7.67

With its wide range of meanings and the background in the Hebrew Bible the use of "brother" in a metaphorical sense seems to be mostly conventional, not conveying strong metaphorical structuring of membership in terms of brotherhood. ${ }^{68}$ In D and S, the term אח often has the broad sense "the other." Most often the term occurs in the idiom

\footnotetext{
${ }^{62}$ The narrow meaning is often made clear by further specifications like "our flesh," "the son of your mother/father" (e.g., Gen 37:27, 42:13; Ps 50:20).

${ }_{63}$ Num 8:26; Deut 18:7; 2 Kgs 9:2; Neh 5:1, 5, 8.

${ }^{64}$ Gen 19:7, 29:4; Judg 19:23; 1 Sam 30:23; 2 Sam 20:9; 1 Chr 28:2; 1 Kgs 9:13; 20:32ff.

${ }_{65}$ According to the Abegg (2003, 22), אח "brother" occurs 77 times in the nonbiblical manuscripts.

${ }^{66}$ Similarly, in D, the term has a concrete, biological meaning in a halakhic context ("daughter of a brother" CD V 8, 10), and in a narrative of past history ("Jannes and his brother" CD V 19). The term "sister" is found 14 times in the DSS, predominantly in halakhic passages. In two cases (4QD ${ }^{a} 14 d 1$ and 4Q502 95 1) the context has been not been preserved to determine its usage.

${ }^{67}$ See Newsom 1996, 247-8. The speech is probably to be understood as Joshua's exhortation to the people who are about to enter the land. The address "woe to you, my brothers" recalls the laments in 1 Kgs 13:30 and Jer 22:18.

${ }^{68}$ In comparison, "brothers" occurs twice in the Hebrew letters from the Bar Kokhba documents with reference to fellow soldiers (P. Yadin 49 I 4; II 9; see also 44 25 where אח אח heas the meanin "another"). In the few Greek letters extant, "brother" in the singular and the plural appears three times in the same letter (P. Yadin 59; see Yadin 2002).
} 
איש-אחיו, "one-another," "one-the other," indicating reciprocity, and

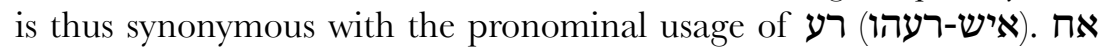
occurs only once in D's community organization layer where it is used in this idiom: in the assembly of all the camps, the members shall be mustered in four groups, the priests, the Levites, the Israelites, and the proselytes - these will be inscribed by their names, "each one after his brother (איש אחר אחיהו)" (CD XIV 5-6 // 4QD 9 V 8-10). This order will then govern their seating order and order of inquiry. The phrase does not need to imply anything other than "one after the other," as indeed Baumgarten and Schwartz $(1995,57)$ translate it. Furthermore, in D's Admonition section, we find the exhortation: "Then each will speak to his fellow (רעהו), each helping the other (אחיו) to be righteous, firmly placing their steps in the Way of God" (CD XX 17-18). Similarly in S, where is used only twice (VI 10,22), the first occurrence falls into the same category: "No one (איש) should speak during the speech of his fellow (רעהו), before the other (אחיהו) has finished speaking."69

Since the brotherhood terminology is rare in the serakhim one section stands out: "brother" is used three times in the section CD VI 11-VII 4 (VI 20; VII 1, 2). Here again, it is the idiomatic usage that mostly defines its usage, but the passage deserves a closer look. As a whole, it sets the "program" for the group; we quote it in part:

They should take care to act in accordance with the exact interpretation of the law for the age of the wickedness (VI 14)... for each to love his brother like himself; to strengthen the hand of the poor, the needy, and the foreigner; for each to seek the peace of his brother; not to be unfaithful against his blood relative (בשרו); to refrain from fornication in accordance with the regulation; for each to reprove his brother in accordance with the precept, and not to bear resentment from one day to the next...(CD VI 20-VII 3)

The "program" has often been considered as one of the earliest traditions of $\mathrm{D}^{70}$ and it has clear affinities with the Holiness Code in

\footnotetext{
${ }^{69}$ is also corrected by editors in 1QS V 25: "No one should speak to his brother in anger..." For 1QS VI 22, see below.

70 Murphy-O'Connor (1971) calls the section CD VI 11b-VIII 3 "Memorandum" and regards it one of the earliest traditions of $\mathrm{CD}$; it is written to remind the members of the initial demands. The passage in VI $11 \mathrm{~b}-\mathrm{VII} 4 \mathrm{a}$ preserves a summary of the laws of the document. Similarly, Davies (1983, 125, 198) argues that this passage contains the "main points of the community's halachah" and is a part of the original Admonition. Stegemann (1992, 146) suggests that this section reflects the legal activity of Judeans who fled to Damascus and its surroundings during the crisis under Antiochus IV Epiphanes.
} 
Lev 19-26. ${ }^{71}$ Leviticus uses the terms עמית (19:11, 15, 17), רע (e.g., 19:13, 18), and אח (e.g., 19:17) of a fellow citizen. For our analysis, it is noteworthy that the command to love one's neighbor has the term רע (Lev 19:18), but CD uses אח instead (CD VI 20); in fact אח is the only term for a fellow member in this section. In comparison $\mathrm{S}$ uses the term רע in speaking about reciprocal love and kindness (1QS II 24-25; VIII 2) and in speaking about reproof of a fellow member (1QS V 24-25). This may well indicate a preference for brother terminology in this early section of $\mathrm{D}$.

Philip Davies (1983, 161-4) has shown that this summary of the laws in CD VI 11b-VII $4 \mathrm{a}$ is in many aspects a mirror image of the criticism of the "princes of Judah" presented in CD VIII 3ff. (par. CD XIX 15ff.). In contrast to love, these enemies take revenge and bear grudge "each man against his brother (אחיו)" and "each one hating his fellow (רעהו)" (VIII 5-6). Davies argues that the "princes of Judah" are not treacherous community members but rather outsiders. When comparing the summary of the laws to the criticism of the princes, he writes $(1983,162)$ :

"Loving one's brother"... may denote in one case specific obligations towards a fellow-member (such as reproving him) and in the other regards for one's fellow Jews, ... [T] he identity of one's fellow will depend on whether one is inside or outside the community, so that criticism may apply equally in either case. The distinction between רע מע may be significant in this respect.

The term רע functions in a similar way in the DSS as it does in the Hebrew Bible. ${ }^{72}$ Thus the variation between and in general is not necessarily of major importance. However considering the total absence of רע in CD VI 1 1b-VII 4a and the fact that these principles present the ideals for the insiders, it appears that the author is here specifically emphasizing the unity of the members and their behavior towards each other in the language of brotherhood.

Turning to S, the plural of אח is found in 1QS VI 22:

${ }^{71}$ Cf. care for the poor and the foreigner in Lev 19:10, 15, 33-34; the need to reprove a fellow member in Lev 19:17; the demand not to bear a grudge but to love one's neighbor as oneself in Lev 19:18, 33-34.

${ }^{72}$ Both in D and in S, רע serves as the main term for designating the "other" in the regulations, penal codes, and in halahkic ordinances. It is clear from many passages that these "fellow members" have a hierarchical order: 1QS V 23; VI 26; 1QSa I 18; 1QH XVIII 27-28. 
He must not touch the drink of the rabbim until he completes a second year among the men of the yahad... If the lot results in him joining the בתוך) yahad, they shall enter him in the order of his rank among his brothers (אחיו ) for the law, for the judgment, for purity, and for the placing of his possessions. And his advice will be for the yahad, as will be his judgment (1QS VI 20b-22).

The passage shows that "brothers" stand in a hierarchical order in relation to each other; there is no equality in this sense. The expression that is perhaps closest to simply "members" in S is אנשי היחד, "the men of the yahad," (1QS V 1; VI 21; VIII 16; IX 19). This is used in the immediate context of VI 22: "He must not touch the drink of the rabbim until he completes a second year among the men of the yahad" (VI 21). Therefore, "among his brothers" and "among the men of the yahad" seem to indicate a similar idea: an individual has his place among the community members - only that in the latter case, he will be a full member and "brothers" might stress this full unity. However, there is no language of brotherhood elsewhere in the document. This is especially noteworthy in the penal code where behavior and attitudes towards other members are the main issues. Without exception the penal code uses רע to denote reciprocity between members (altogether nine times in 1QS VI 24-VII 27; also three times in 1QS VI 1-8, and once in 1QS VIII 20; three times in $\left.4 Q^{\mathrm{a}} 10 \mathrm{II} 2,9,15\right) .^{73}$

The same phrase "among his brothers" is found in 1QSa in the section that introduces graduated duties depending on one's age and then describes the general principles for all those fulfilling their service: ${ }^{74}$

${ }^{73}$ The penal codes in S and D similarly refer to members with ואשר (whoever). One passage in S that stresses fellowship reads: "Whoever retorts to his fellow (רעשהו) with stubbornness, (and) speaks with brusqueness, ruining the foundation of fellowship (יםוד עמיתו) he has with him, defying the authority of his fellow (רעהו) who is enrolled ahead of him, [he h] as taken the law into his own hands" (1QS VI 25-27). The hierarchical order is considered as a natural part of the society of members; respect for that order is a requirement for the "fellowship." The term עמית, "fellow, friend; association of people," is also used in the quotation of Lev 25:14 in 4QD 3 4-5: one is not to harm his fellow in business.

${ }^{74}$ Nevertheless, it is not clear where the sentences break. Some see the "chiefs of the households of the congregation" (I 16) as the beginning of a new sentence; accordingly, this group is the subject until at least the end of I 18 (Charlesworth and Stuckenbruck 1994, 113; García Martínez and Tigchelaar 1997-1998, 1:101). Others take the "chiefs of the households of the congregation" (I 16) together with the "sons of Aaron" of I 15 (e.g., Schiffman 1989, 21) as the authorities of the community (as in I 23-25). Consequently, lines 17-19 speak of members in general, which seems plausible. For the titles, see below. 
... in accordance with his intelligence, with perfection of his behavior, (he) shall gird his loins to remain steadfa[st, d] oing his allotted duty among his brothers. [Depen]ding on whether (he has) much or little, [one] will be more or less honoured [than] his fellow (מרעהו). When the years of a man increase, they shall assign him a task in the ser[vi]ce of the congregation according to his strength (1QSa I 17b-19).

The order of rank among the members is again explicitly stressed here. The terminology of brothers indicates a group that has similar duties. This is supported by another passage where the sons of Aaron, the priests, are called brothers of the chief priest (1QSa II 12-13, though partly reconstructed; similarly, 1QM XIII 1; XV 4, 7; 4QD 5 II 4). Brother terminology thus represents colleagues, i.e., similar members of a smaller group (such as priests). This usage accords well with that in late biblical books where (Levitical) priests are referred to as brothers (e.g., Ezra 3:8; 1 Chr 14:12; 23:32; 24:31; 2 Chr 29:15; Num 8:26). Likewise "brothers" stand for priestly circles in the War Scroll (1QM XIII 1; XV 4, 7). ${ }^{75}$ All in all, brother metaphors are conventional; they highlight similar duties and reciprocal relationships, sometimes also unity, but no attempt is seen to hide the hierarchical relationships between the "brothers."

\section{Concluding Reflegtions on Hierarchy and Equality}

The organizational structure of the sectarian communities is a difficult and highly contested subject, including the question whether the organization/s should be characterized as egalitarian or hierarchical or something in between. ${ }^{76}$ The choice of family metaphors can be informative for the debate. Some initial findings deserve attention.

Overall, parent-child metaphors represent the most explicit and clear cases of metaphorical structuring in the DSS. On the other hand sibling and son-ship expressions are very conventional; their metaphorical

${ }^{75}$ Other occurrences of "brothers" in sectarian texts include 4Q177 (4QCatena ${ }^{a}$ ) col. IV, where it is found together with "sons/children of the light." The lines are fragmentary, and it is not clear to whom "their brothers" in IV 11 refers: "... and their brothers through the <scheming> of Belial, and he will triumph th[em...]."

${ }^{76}$ As Regev 2003, 2004, proposes - he describes the yahad as "semi-egalitarian." Jastram $(1997,375)$ suggested that the Qumran movement "greatly valued hierarchy but at the same time it strove to prevent abuse of authority and to promote unity among members." "Egalitarianism" in the modern sense is a somewhat problematic concept in the discussion, see Elliott 2003. 
nature is not always emphasized. Yet, son-ship language, unlike brotherhood language, was found to be frequent and probably significant in the sect's conceptual world. At the same time, familial metaphors do not form a consistent system that can be found throughout the texts; for example, leader figures play the role of the father in addition to God.

Of the familial terms surveyed in the Scrolls, "brother" carries the greatest potential for invoking the sense of equality among the members. In light of this, it is significant that the term rarely occurs in the Rules. The few times "brother" appears, it is as an equivalent term to "fellow" where it does not express familial intimacy. Significantly, the term appears in several cases within a context that outlines hierarchical structures. This circumstance allows for the possibility that the term was generally avoided specifically because of its inappropriateness for the character of the sect. At the same time, in contexts in which hierarchy is enforced, it may have been "safe" to use the term to advance feelings of unity and mutual love between members. In response to those scholars who claim that the yahad in the Community Rule was more democratic than the Damascus Covenant in D (e.g., Regev 2003, 2004), it is significant that none of the communities behind S or D appear fond of the term.

The passage in $\mathrm{D}$ in which the term "brother" occurs frequently, CD VI 17-VII 4, stands out as unique among the Rules. This passage probably is one of the earliest segments of the document. One possibility is that this sectarian community did not use the yahad language because it had the brother language to express and promote togetherness and to evoke an ideal picture from the biblical era when the people of Israel were considered one big family of tribal brothers. The new covenant formed the new people. The language expresses unity but not democracy. Perhaps this language was needed at the stage in which the movement created a distinct identity of its own against the outsiders. Or perhaps the early Damascus sect did value egalitarian aspects in its structure more than the later authoritarian setting (evident in the extensive power of the mevaqqer) would have us believe.

In $\mathrm{S}$ the language of son-ship is the preferred terminology. As this rhetoric primarily directs the individuals into identifying themselves as being part of the group in that they share a common origin and quality, it also promotes reliance on and submission to God and the leaders alike; the language fosters submissiveness on different levels and encourages the members to define themselves as honorable but 
dependent family members. Such submissiveness can be used (or exploited) by leaders to instill obedience - a highly valued quality in S. Although all members are children together (e.g., "sons of light") at a high level of abstraction, this does not imply equality at lower levels of categorization. Like "yahad" these expressions promote unity of the group against outsiders. The common bonds are particularly marked in the dualistic metaphor of light versus darkness, but this is not a community of equals. Among themselves the members are related to each other in a more complicated manner.

The language of son-ship appears in $\mathrm{D}$ as well where it expresses the relationship between members and leaders on the one hand and between members and God on the other. As this rhetoric directs individuals to identify themselves as being part of the group, it also, together with the stressed parental metaphors, serves to encourage them as sons/children to be obedient towards the fatherly (and motherly) leaders who, at least in the case of the mevaqqer, act on behalf of God. D describes the mevaqqer as acting as a father towards his children/members. His lofty position resembles that of the maskil in $\mathrm{S}$ which uses less prominent fatherly characteristics than $\mathrm{D}$ does but places him equally high above the members, close to God. This raises the question as to why only D presents the main leader in pronounced fatherly terms and also entitles other community officials Fathers and Mothers. Is there a connection between the difference in rhetoric and the nature of the communities? If we assume that the $\mathrm{D}$ community consisted of families whereas the one reflected in S apparently lacked married couples, there may well be a connection. The forming of families in any sectarian setting tends to create a delicate power-dynamic between the family units and the sect. There may well have been a tension between biological parents, the fathers in particular, and the sectarian leadership when the latter aspired to take over some of the fathers' traditional power and in some respect to replace them. It is therefore reasonable to view the fatherly and motherly metaphors applied to leaders in D as one strategy to persuade members to view the the leaders as parents, rather than their biological ones. Nevertheless the social identity perspective reminds us that the metaphorical usage of familial terms does not require that members stop categorizing themselves as part of biological families. Their identity as family members and their identity as sect members could be prominent in distinct situations.

The leader figure in the Hodayot takes on an explicitly fatherly role; motherly images are also used to describe his relationship to his follow- 
ers. This presentation, combined with the occasional negative stance towards the biological family unit, further enhances the parental role of the leader. Thus, the tendency to evoke parental images with respect to a leader may have been widespread in the sect, although we do not know the relationship between $1 \mathrm{QH}^{\mathrm{a}}$ and the communities behind $\mathrm{S}$ or D.

In sum, there was no brotherhood at Qumran - not at least in their perception and in their way of speaking about themselves. In our survey of familial language, we found very little evidence of familial metaphors in egalitarian use. Overall the family language evokes images that look more like a patriarchal household than a brotherly guild. Familial metaphors highlight hierarchical relationships - God as Father, leaders as fathers/mothers, members as children, members as brothers holding different responsibilities and ranks - rather than notions of relationships of equals.

Finally we should briefly consider our exploration of fictive familial language in the Scrolls from a broader socio-cultural perspective. The use of familial metaphors is a common trait among voluntary associations in antiquity. The early Jesus followers utilized metaphorical familial language to a greater extent than apparent in the sectarian literature of the DSS. Other types of voluntary associations in GrecoRoman antiquity, such as philosophical schools, professional guilds, and cult associations in many ways functioned as an extended family and commonly expressed intimacy and affection between members through familial metaphors (Kloppenborg 1996, Duling 1995). The tendency to use family metaphors existed in early synagogues as well (Brooten 1982). Recent years have seen an increasing scholarly interest in the use of familial language among voluntary associations in general (Harland 2005, 2007) and in the early Jesus movement in particular (Moxnes 1997, Aasgaard 2004). Nevertheless the DSS have not been the subject of a similar inquiry. It is thus our hope that our examination of the DSS may provide a contribution for future comparative studies on the usage of familial metaphors in the various voluntary associations of Antiquity that will further advance our understanding of the Essene sect within its Jewish and Hellenistic milieu during the Second Temple Period. 